\title{
THE FUNCTIONAL SLOTS OF FINITE VERB TAGMAS
}

\author{
Muhartoyo \\ English Department, Faculty of Humanities, BINUS University \\ Jln. Kemanggisan Ilir III No. 45, Kemanggisan-Palmerah, Jakarta Barat 11480
}

\begin{abstract}
Tagmemic analysis is a comprehensive language analysis introduced by Prof. Kenneth L. Pike and Evelyn G. Pike from the Summer Institute of Linguistic, USA. This analysis enables linguists to study a language, especially the one which has not been studied before, in a more comprehensive manner. This study attempts to reveal functional slots that be filled by finite verb tagmas in English. The data for this study were taken from various published printed media which have high standard English. Ten different sentences were selected to be analyzed using Tagmemic analysis. Slot-role and four-cell analysis were conducted in this study. The result of analysis shows that Predicate Slot in English must be filled by finite verb tagmas. As the predicate is the essential or obligatory element in a clause construction, the ability to identify the occurrence of finite verb tagmas in English is compulsory. Finite verbs tagmas have different roles depending on the type of clauses. Tagmemes following the Predicate slots also vary depending on the transitivity of the finite verbs.
\end{abstract}

Keywords: tagmemic analysis, finite verbs

\begin{abstract}
ABSTRAK
Analisis Tagmemik adalah analisis bahasa yang komprehensif yang diperkenalkan oleh Prof Kenneth L. Pike dan Evelyn G. Pike dari Summer Institute of Linguistic, USA. Analisis ini memungkinkan ahli bahasa untuk mempelajari bahasa, terutama yang yang belum dipelajari sebelumnya, secara lebih komprehensif. Penelitian ini berusaha untuk mengungkapkan slot fungsional yang diisi oleh tagma verba finit dalam bahasa Inggris. Data untuk penelitian ini diambil dari berbagai media cetak dengan bahasa Inggris standar tinggi. Sepuluh kalimat berbeda dipilih untuk dianalisis dengan menggunakan analisis Tagmemik. Analisis slot-role dan four-cell dilakukan dalam penelitian ini. Hasil analisis menunjukkan bahwa slot predikat dalam bahasa Inggris harus diisi oleh tagma verba finit. Karena predikat adalah elemen penting atau wajib dalam konstruksi klausa, kemampuan untuk mengidentifikasi kehadiran tagma verba finit dalam bahasa Inggris adalah wajib. Tagma verba terbatas memiliki peran yang berbeda tergantung pada jenis klausa. Tagmeme yang mengikuti slot predikat juga bervariasi tergantung pada transitivitas dari verba finit.
\end{abstract}

Kata kunci: analisis tagmemik, verba finit 


\section{INTRODUCTION}

The important role of language in communication has inspired people from generation to generation to learn about it. The need to learn other languages is inevitable when we want to communicate with the native speakers of the language for various purposes such as economic, social, and cultural purposes. This need leads to the development of linguistics, the scientific study of language.

The development of linguistics is also influenced by the Renaissance Era in Europe which results in the revival of various sectors such as architecture, paintings, sculpture, and literature. During this period, the economic and industrial development in Europe was very progressive. The exploration for raw materials in new territories was progressively conducted. The exploration was usually initiated by sending troops to occupy the new territories. If the new territories were successfully occupied, traders would be sent to take care of the economic sectors. When the security, social and economic conditions were conducive enough, the missionaries would be sent to preach Christian religious teachings in the new territories. To ensure successful mission, each missionary was required to master the local language. The mastery of local languages was not only important for missionaries but also for the administrative purposes of the colonial government (Wahab, 1990).

In their efforts to master the local language, the missionaries used traditional grammatical analysis from Greeks and Latin. In many cases, this kind of analysis (traditional grammar analysis) turned out to be insufficient and inappropriate. Therefore, they were looking for new approaches which could help them perform their mission. This situation induced the proliferation of new linguistic approaches and one of them was tagmemic analysis (Wahab, 1990).

Tagmemic analysis offers a comprehensive analytical approach which is worth considering in language analysis. Tagmemic analysis has been successfully used to describe many languages which have not been studied before. A number of Red Indian and African languages have been analyzed using tagmemic analysis. Some vernacular languages in Indonesia have also been analyzed using tagmemic model.

Tagmemic analysis is concerned primarily with the grammatical analysis in which the basic or the smallest grammatical unit is called tagmeme. This theory was introduced by Prof. Kenneth L. Pike, from Michigan University, USA and the founder of Summer Institute of Linguistic. Unlike Structuralism which ignores the functions of a linguistic form and concentrated only on forms, Tagmemics integrates the form and the function of a linguistic form together into a linguistic entity.

\section{Tagememic Analysis}

To make it easier for interested readers to understand the analysis and discussion in this study, especially for those who are not familiar with tagmemic analysis, the writer feels it necessary to highlight some basic principal of tagmemic analysis. In Tagmemics, stresses are given to the hierarchical ordering of grammatical units into ranks of levels consisting of morphemes, words, phrases, clauses, sentences, paragraphs, and discourses. In the process of grammatical analysis, tagmemics always goes in favor of string constituent analysis, and have many cuts. It is different from Immediate Constituent analysis in which grammarians apply binary cuts in their grammatical analysis. Unlike a structural analysis, Tagmemics requires identification of functions and categories and not merely their naming. It can be stated that it is a "slot and filler grammar". A slot is a position in a construction string. Meanwhile a filler class is similar with part of speech in traditional grammar like nouns, verbs, adverbs that can fill a slot. But neither the slot nor the filler itself is important, it is the tagmeme which is significant. The slot is the function such as subject, predicate, object, etc. and filler 
being the category such as nouns, verbs, adverbs, adjectives, etc. A tagmeme, therefore, is the corelation of a slot and the filler class that fills in that slot.

In other words, tagmemic theory is based on the concept of tagmeme which is part of a grammatical construction consisting of 4 different signifying elements i.e. slots, categories, roles, and cohesions (Soeparno, 2002).

Slot is one of the four tagmeme elements in the form of a position in a grammatical construction frame that must be filled by a function tagmeme element. In the clause construction for example, the function tagmeme elements consist of subject, predicate, object, and adjunct. In other lower levels of grammatical construction frame, the function tagmeme usually consists of nucleus and margin. Slot, therefore, answers the questions of "where does the linguistic unit go in the construction frame?"

Category is the manifesting item of a slot which is in the form of linguistic units such as morphems, words, phrases, clauses, aleneas, monologs, dialogues, and discourses. Categories can be further divided into smaller units or sub-categories. Phrases can be divided into noun phrase, and verb phrase and clauses can be classified into transitive, intransitive, and equative clauses. To make it easy, category answers the question of "what kind of linguistic unit is it?"

Role is one of the four features of tagmeme which signifies the role of a linguistic unit such as "actor" / "doer" and "undergoer". It answers the questions of "why is this unit here?", "What is its function?"

Cohesion is the last feature of tagmeme which controls inter-tagmeme relation. Cohesion usually deals with transitivity of verbs, case marking, subject verb agreement, and existence (obligatory or optional). It answers the question of "How does this linguistic unit relate to other units and wider context?"

As tagmemic analysis deals with all levels of grammatical hierarchies, the analysis may result in sentence level tagmemes, clause level tagmemes, phrase level tagmemes, word level tagmemes and morpheme level tagmemes. Cook (1969) summarized the system of tagmemic grammatical levels as clearly shown in the following chart.

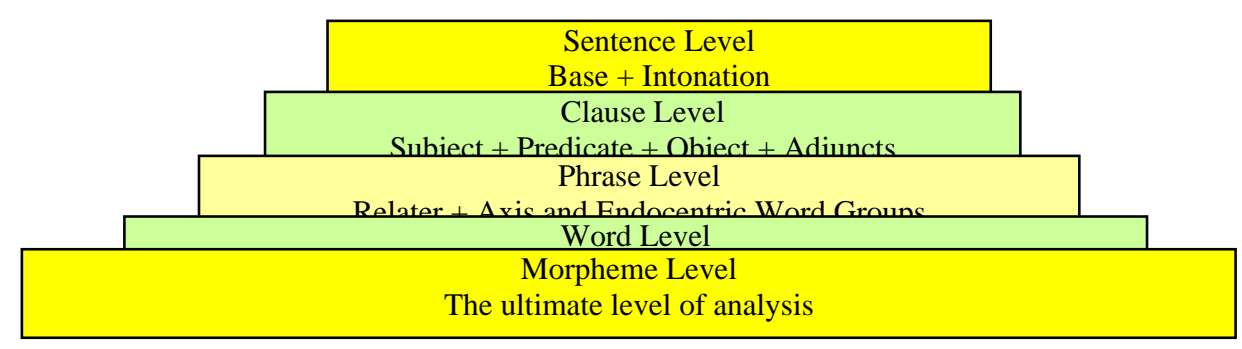

Figure 1 The system of grammatical level

In tagmemic analysis a clause is considered as a syntactic construction built by some tagmas supra segmental or final intonation contour elements. A tagma is defined as the correlation of function and form (Cook, 1969: 19). It is also called a tentative tagmeme. Actually tagmas are not only understood as the correlation of function and form but also of semantic filler or role and cohesion. These four features can be clearly seen in the Tagmemic analysis by using a four-celled array in which the first cell is filled by a function, the second one is filled by a role, the third one is filled by a category and the fourth cell is filled by cohesion. 
In the first approximation, the analyst cuts the clause according to the slot-class and role correlative or tagmas, and the tagmas are considered as invariant units. Every tagma is thought as if a tagmeme, so every tagmeme has only one allotagma. Tagmas are then grouped as an etic unit of grammar. After initial investigation tagmas that are the same are grouped as allotagmas of one tagmeme and those that are different are grouped into other tagmemes.

These are three rules to decide whether the tagmas are allotagmas of one tagmemes or not: (1) Tagmas which are different in form but have the same functional meaning or role and the same position in the string are grouped as allotagmas of the same tagmeme. They are listed as the alternate fillers in tagmemic slots, for example: She writes a letter, He writes a letter, John writes a letter. She, $\mathrm{He}$, and John have different forms from each other but they have the same role and position. So they are considered as the allotagmas of one tagmeme i.e. subject tagmeme. (2) Tagmas that are only different in role or meaning belong to the same tagmeme, although the structural meaning of a tagmeme is the principle identifying feature. Unless the meaning difference is correlated with parallel difference in filler class or position in the string, the tagmemes are grouped as allotagmas of the same tagmeme, examples: Andi gives a nice present to Ani, Abas is given a nice present by Ani, Anjani seems to be happy. Andi, Abas, and Anjani, have different roles from each other but they are the same filler class which is mutually substitutable and they have the same position. Therefore, they can be grouped as the allotagmas of the same tagmeme, which is subject tagmeme. (3) Tagmas differing in position alone may belong to the same tagmeme, and would then merely positional variants of the same unit. Unless the change of position is correlated with the change of form, the tagmas are considered as variants of one tagmeme, for examples: You will begin to work next week, Will you begin to work next week. You in the first and in the second clause have different positions, but they have the same forms and the same roles. So they can be grouped as the allotagmas of the subject tagmeme (Cook, 1969).

The correlation of tagmas and allotagmas to tagmemes is similar to that of morph and allomorphs to morphemes, also with that of phones to allophones and phonemes. In order words, it can be stated that a tagma is preliminary form of a tagmeme, whereas an allotagma is a member of the same tagmeme after the initial investigation. In Tagmemic Analysis tagmeme is the smallest unit of grammar.

\section{Finite Verbs}

Finite verb is defined in various ways. According to Oxford Advanced Learner's Dictionary of Current English, finite verb is a verb that agrees with a subject in number and person (Hornby, 1980). Meanwhile in his book Guide to Pattern and Usage in English, Hornby defines finite verbs are those forms other than non-finite verbs. The non-finite verbs are the infinitives (present and perfect, with or without to), the present and past participles, and the gerund (or verbal noun) In addition, Hornby says that there are 24 special finite verbs which have many functions for example, they are used in the formation of negative and interrogative sentences; they are used to avoid repetition (in short answers and 'tag' questions). This kind of finite verbs are also required in the emphatic affirmative. They are also called modal verbs as they are used to express certain moods. The complete list of the 24 special finite verbs is in Table 1. 
Table 1 The complete list of 24 special finite verbs

\begin{tabular}{cccccc}
\hline & & Non-finite Forms & & \multicolumn{2}{c}{ Finite Forms } \\
\hline & Infinitive & Present Participle & Past Participle & Present Tense & Past Tense \\
\hline 1 & be & being & been & am, is, are & was, were \\
2 & have & having & had & have, has & had \\
3 & do & doing & done & do, does & did \\
4 & - & - & - & shall & should \\
5 & - & - & - & will & would \\
6 & - & - & - & can & could \\
7 & - & - & - & may & might \\
8 & - & - & - & must & - \\
9 & - & - & - & ought & - \\
10 & - & - & - & need & - \\
11 & - & - & - & dare & - \\
12 & - & - & & &
\end{tabular}

According to Harman and House (1950), a popular definition of a verb states that a verb asserts or predicates. Another grammarian, Zandvoort (1966), says that a finite verb is one expressing or implying tense, number, person and mood. It can be inferred that finite verbs are the verbs that have to adjust their forms based on the number of subject, mood, and tense of the sentence.

\section{The goals and function}

This study is aimed at finding out the functional slots of finite verbs in English by using tagmemic analysis. The function of this is to enrich interested readers with different analytical approach in linguistic study.

\section{RESEARCH METHOD}

As tagmemic analysis covers all hierarchical levels of grammar, the scope of this study will be limited on simple sentences or independent clauses. The analysis will include four celled-diagram analysis.

To achieve the goals of this study the writer collects the data from some publications which are known for their high standard usage of English. Those publications are the Jakarta Post, Times Magazine, The Economist, and the Wall Street Journal. Ten sentences from those publications were randomly selected. The selected sentences representing different types of sentences are then analyzed using Tagmemic theory.

\section{RESULTS AND DISCUSSION}

\section{Selected Sentences}

After scanning articles from various sources mentioned above, the writer obtains a number of sentence containing various types of finite verbs. Those sentences are as follows:

- $\quad$ We will do it gradually. (The Jakarta Post, 4 January 2012:1) 
- Indonesia banks received hundreds of trillions of rupiah in liquidity support from the central bank in government bonds to keep their business alive by taking out returns from the debts papers. (The Jakarta Post, 4 January 2012:1).

- The campaign has expanded from Greater Jakarta to other parts of archipelago, including Surakarta, Central Java; Palu, Central sulawesi; and Palembang, South Sumatra. (The Jakarta Post, 4 January 2012:1).

- Hundreds of donated rubber sandals are displayed at the headquarters of the National Commission for Child Protection in Jakarta on Tuesday. (The Jakarta Post, 4 January 2012:1).

- $\quad$ In emerging markets, skepticism and schadenfreude abaund. (The Wall Street Journal, 3 January 2012:1)

- $\quad$ The central element was an interest-rate subsidy programme worth 17 trillion dong (\$1 billion). (The Economist, Sept-Oct 2009:32)

- $\quad$ It is exiting when I am lying on the treatment table. (The Wall Street Journal, January 3, 2012:1).

- For most of its history, psychology had concerned itself with all that ails the human mind: anxiety, depression, neurosis, obsessions, paranoia, delusions. (Times, February 28, 2005:31)

- $\quad$ How could I suspect that Inong's good deeds were ilicit? (The Jakarta Post, 5 January 2012:9).

- $\quad$ Invest time and energy in friends and family. (Times, February 28, 2005:33)

\section{Data Analysis}

The ten selected sentences above will be analyzed to identify clause-level tagmemes by slotrole and draw lines showing the extent of each tagmeme.

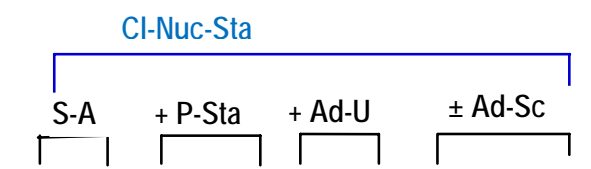

a) We will do it gradually. (The Jakarta Post, 4 January 2012:1)

b)

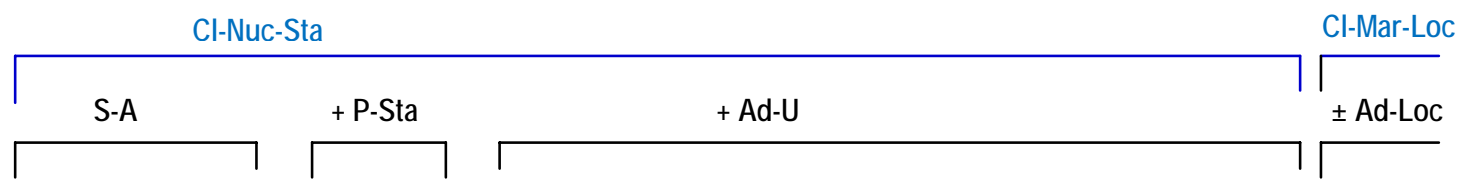

c) Indonesia banks received hundreds of trillions of rupiah in liquidity support from the central

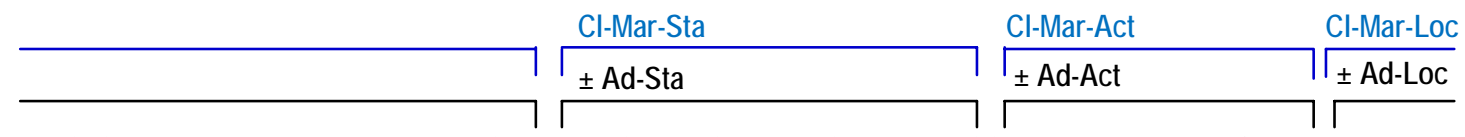

bank in government bonds to keep their business alive by taking out returns from the debts

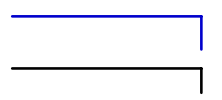

papers. (The Jakarta Post, 4 January 2012:1).

\begin{tabular}{|c|c|c|c|}
\hline Cl-Nuc- & & Cl-Mar-Loc-1 & Cl-Mar-Loc-2 \\
\hline S-A & + P-Sta & \pm Ad-Loc-1 & \pm Ad-Loc-2 \\
\hline
\end{tabular}


d) The campaign has expanded from Greater Jakarta to other parts of archipelago, including Surakarta, Central Java; Palu, Central sulawesi; and Palembang, South Sumatra. (The Jakarta

Post, 4 January 2012:1).

\begin{tabular}{|l|l} 
Cl-Nuc-Sta & Cl-Mar-Loc \\
\hline S-U & + P-Sta \\
\hline
\end{tabular}

e) Hundreds of donated rubber sandals are displayed at the headquarters of the National

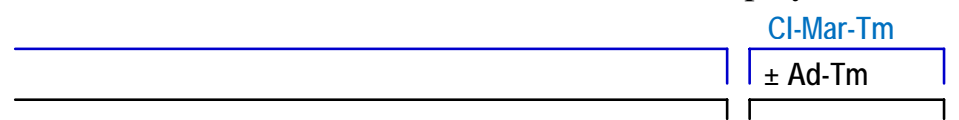

Commission for Child Protection in Jakarta on Tuesday. (The Jakarta Post, 4 January

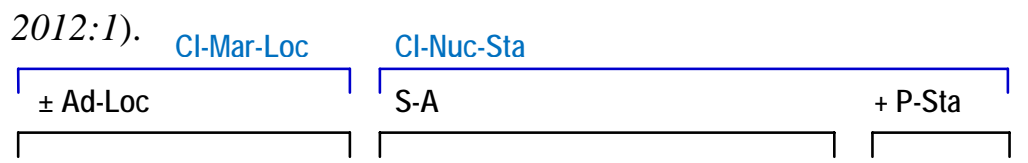

f) In emerging markets, skepticism and schadenfreude abaund. (The Wall Street Journal, 3

January 2012:1)

\begin{tabular}{|lll}
\multicolumn{2}{c}{ Cl-Nuc-Sta } & Cl-Mar-Sc \\
\hline S-It & + P-Sta +Ad-Sc-1 & I Ad-Sc-2 \\
\hline
\end{tabular}

g) The central element was an interest-rate subsidy programme worth 17 trillion dong (\$1

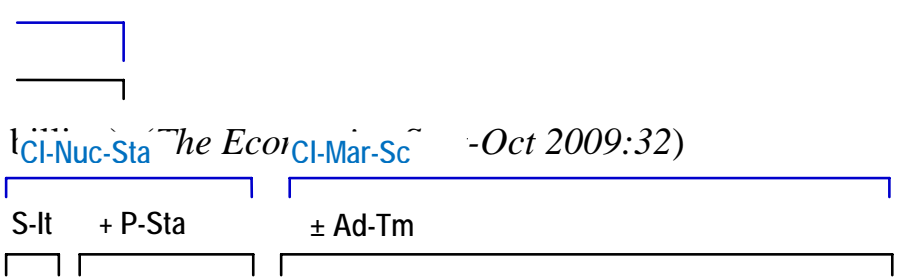

h) It is exiting when I am lying on the treatment table. (The Wall Street Journal, January

3, 2012:1).

\begin{tabular}{|c|c|c|c|}
\hline Cl-Mar-Sc & $\mathrm{Cl}-\mathrm{N}$ & & \\
\hline \pm Ad-Sc-1 & S-A & + P-Sta & \pm Ad-U $\quad \pm$ Ad-Sc-2 \\
\hline
\end{tabular}

i) For most of its history, psychology had concerned itself with all that ails the human mind: Cl-Mar-Sc

\section{\pm Ad-Sc-3}

anxiety, depression, neurosis, obsessions, paranoia, delusions. (Times, February 28, 2005:31)

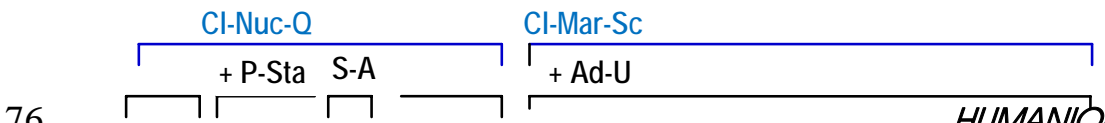


j) How could I suspect that Inong's good deeds were ilicit? (The Jakarta Post, 5 January

2012:9)

Cl-Nuc-Com

P-Com + Ad-Sc

k) Invest time and energy in friends and family. (Times, February 28, 2005:33)

\section{Abbreviations with some definitions and symbols used in the analysis}

A $\quad=$ Actor - The term (participant) which performs the action of the verb; or is in analogous relation to the verb.

Adj = Adjective

Adv $\quad=$ Adverb

Act $\quad=$ Action

Actv $=$ Active

Ad $\quad=$ Adjunct - An unfocused non-predicate, noncomplement tagmeme within the clause.

Co $\quad=$ Complement

COS $=$ Character of Subject

Com $\quad=$ Command

Clause $\quad=$ The minimum unit in which a proposition is stated, i.e. in which something is said about terms; or in which a term or terms is (are) part of a statement, question, command, wish.

Clause root $=$ The string which fills the nucleus of a clause; with function of statement, question, command, or wish, involving only a term or terms which are instrumental in determining the transitivity.

DepCl = Dependent Clause

$\mathrm{Eq} \quad=$ Equative

I $\quad=$ Intransitive

InfPh = Infinitive Phrase

It $\quad=$ Item

Loc $\quad=$ Location

Mar = Margin-The part of a construction which is more dependent, has a more restricted occurence and could generally not substitute for the construction as whole.

Modif $=$ Modifier

$\mathrm{NP} \quad=$ Noun Phrase

Nuc = Nucleus - The part of a construction which is most independent, is a member of a large class, occurs in more grammatical slots, and has a more central semantic role.

$\mathrm{P} \quad \quad=$ Predicate

Pass $\quad=$ Passive

$\mathrm{Pi} \quad=$ Impersonal Pronoun

Pp $\quad=$ Personal Pronoun

$\mathrm{PPh} \quad=$ Prepositional Phrase

$\mathrm{PrPtcPh}=$ Present Participle Phrase

$\mathrm{Q}=$ Question

$\mathrm{RdCl} \quad=$ Reduced Clause

$\operatorname{RfPr} \quad=$ Reflective Pronoun

Sc $\quad=$ Scope - The term (participant) which denotes the direction or goal toward or away from which the action of verb is directed.

Sta $\quad=$ Statement 


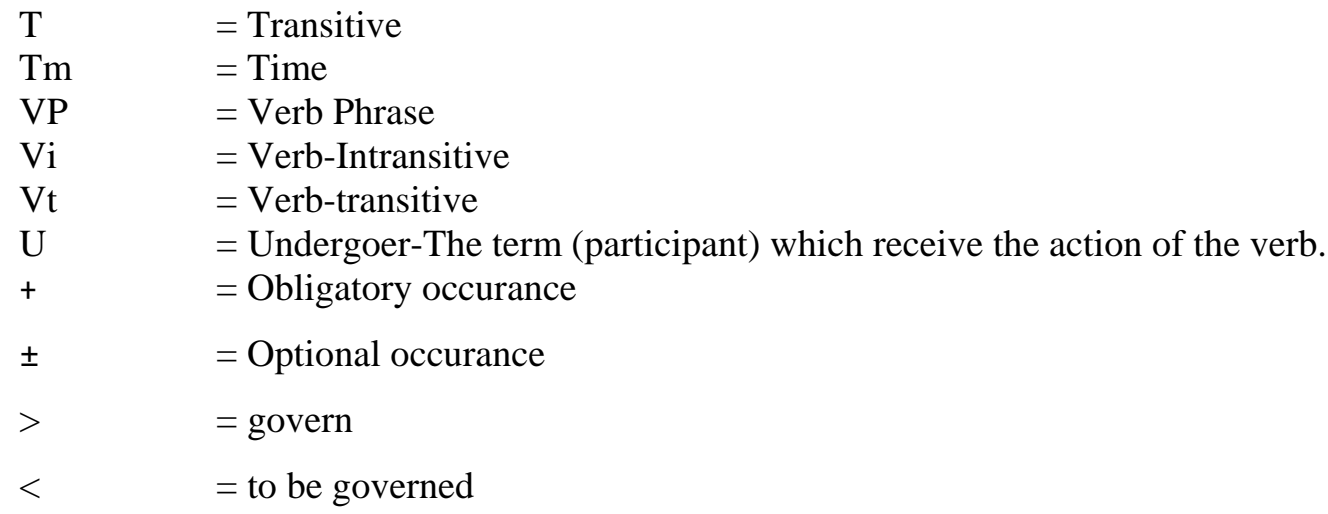

\section{Four cell-diagram analysis}

a) We will do it gradually.

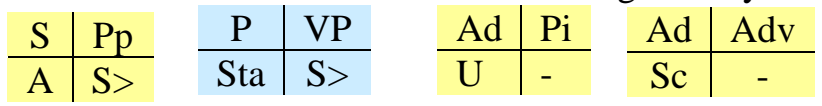

b) Indonesia banks received hundreds of trillions of rupiah in liquidity support from the

\begin{tabular}{|c|c|c|c|c|c|c|}
\hline S & NP & $\mathrm{P}$ & $\mathrm{Vt}$ & $\mathrm{Ad}$ & NP & $\mathrm{PPh}$ \\
\hline $\mathrm{A}$ & $\mathrm{S}>$ & Sta & $\mathrm{S}>$ & $\mathrm{U}$ & - & - \\
\hline
\end{tabular}

central bank in government bonds to keep their business alive by taking out returns from

\begin{tabular}{|c|c|c|c|c|}
\hline Ad & $\mathrm{PPh}$ & Ad & InfPh & $\mathrm{PPh}$ \\
\hline Loc & - & Modif & - & \begin{tabular}{l|l} 
Act & - \\
\end{tabular} \\
\hline
\end{tabular}

the debts papers.

c) The campaign has expanded from Greater Jakarta to other parts of archipelago, including
\begin{tabular}{l|l}
$\mathrm{S}$ & $\mathrm{NP}$ \\
\hline $\mathrm{A}$ & $\mathrm{S}>$
\end{tabular}
\begin{tabular}{c|c}
$\mathrm{P}$ & $\mathrm{Vt}$ \\
\hline Sta & $\mathrm{S}>$
\end{tabular}
\begin{tabular}{c|c} 
Ad & PPh \\
\hline Sc & -
\end{tabular}
\begin{tabular}{c|c} 
Ad & PrPtcPh \\
\hline Sc & -
\end{tabular}

surakarta, Central Java; Palu, Central sulawesi; and Palembang, South Sumatra.

d) Hundreds of donated rubber sandals are displayed at the headquarters of the National

$$
\begin{array}{l|ll|ll|l}
\mathrm{S} & \mathrm{NP} \\
\hline \mathrm{U} & \mathrm{S}> & \mathrm{P} & \mathrm{Vt} & \mathrm{Ad} & \mathrm{PPh} \\
\cline { 2 - 4 } & \text { Pass } & \mathrm{S}> & \text { Sc } & -
\end{array}
$$

Commission for Child Protection in Jakarta on Tuesday.

$$
\begin{array}{c|cc|c}
\text { Ad } & \text { PPh } & \text { Ad } & \text { PPh } \\
\hline \text { Loc } & - & \text { Tm } & -
\end{array}
$$

e) In emerging markets, skepticism and schadenfreude abaund.
\begin{tabular}{c|c} 
Ad & $\mathrm{PPh}$ \\
\hline Loc & -
\end{tabular}
\begin{tabular}{l|l} 
S & NP \\
\hline A & S>
\end{tabular}
\begin{tabular}{c|c}
$\mathrm{P}$ & $\mathrm{Vi}$ \\
\hline Sta & $\mathrm{S}>$
\end{tabular} 
f) The central element

\begin{tabular}{|c|c|c|c|}
\hline \multicolumn{2}{|c|}{ was } & \multicolumn{2}{|c|}{ an interest-rate } \\
\hline $\mathrm{P}$ & $\mathrm{Vi}$ & $\mathrm{Ad}$ & NP \\
\hline $\mathrm{Eq}$ & $\mathrm{S}>$ & Co & \\
\hline
\end{tabular}

worth 17 trillion dong

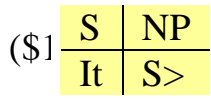
$\mathrm{Eq} \mid \mathrm{S}>$

(\$1 billion).

g) It

\begin{tabular}{|c|c|c|c|c|c|c|c|}
\hline \multicolumn{2}{|l|}{$t$} & \multicolumn{2}{|c|}{ is } & \multicolumn{2}{|c|}{ exiting } & \multicolumn{2}{|c|}{ when I am lying } \\
\hline & NP & $\mathrm{P}$ & $\mathrm{Vi}$ & Ad & Adj & Ad & DepCl \\
\hline & $\mathrm{S}>$ & $\mathrm{Eq}$ & $\mathrm{S}>$ & Co & - & $\overline{\mathrm{Tm}}$ & - \\
\hline
\end{tabular}

h) For most of its history, psychology had concerned itself with all that ails the

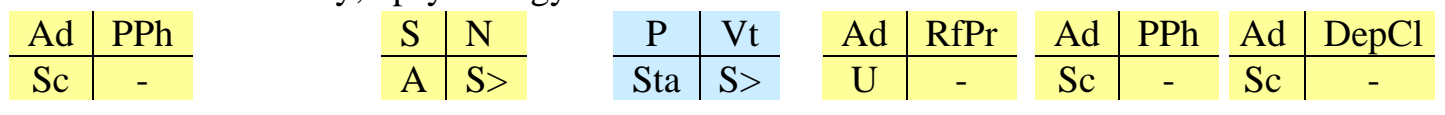

human mind: anxiety, depression, neurosis, obsessions, paranoia, delusions.

i) How could I suspect that Inong's good deeds were ilicit?

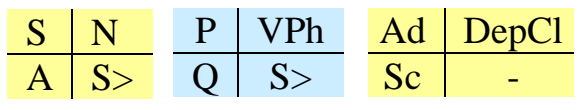

j) Invest time and energy in friends and family.

\begin{tabular}{c|cc|cc|c}
$\mathrm{P}$ & $\mathrm{Vt}$ \\
\hline Com & $\mathrm{S}>$ & Ad & NP \\
\hline U & - & $\quad$ Ad & PPh \\
\hline Sc & -
\end{tabular}

\section{Analysis Description}

The Slot-role analysis shows two-level analysis. The first level analyzes the clause based on slot role analysis in which the two slots are identified i.e. nucleus and margin. As mentioned earlier, nucleus is the part of a clause construction which is most independent. On the other hand, margin is the part of a clause construction which is more dependent. On the other hand, the second level analysis goes deeper into smaller units of the clause which are Subject tagmem, Predicate tagmem, and Adjunct tagmem. The data analyses show that predicate tagmems are always filled by finite verbs. The finite verbs from the ten sentences are: will do, received, has expanded, are displayed, abound, was, is, am lying, had concerned, ails, suspect, and invest.

The four-cell analysis gives a more tangible evidence that Predicate tagmem can only be filled by finite verbs. Likewise this kind of analysis has proved that finite verbs have different roles when filling Predicate slots depending on the type of sentences i.e. statement, command, or question. The tagmemes following the finite verb tagmas also vary depending on the transitivity of the verbs. The transitive finite verb will be followed by Adjunct with Undergoer role, the intransitive finite verbs will be followed by adjunct with Scope role, while equative finite verbs will be followed by Adjunct with Complement role. 


\section{CONCLUSION}

Tagmemic analysis offers a detailed grammatical analysis than traditional grammatical analysis. This kind of analysis will enable linguists to conduct deeper analysis to any language beyond its surface structure. Many languages, especially the ones which have never been studied before, have been successfully analyzed by Tagmemic analysis. The study using ten sample sentences from various sources have proved that finite verbs tagmas can only fill Predicate tagmeme in English. As the minimum requirement of a clause is a clause root filled by a clause nucleus consisting of a Subject tagmeme and a Predicate tagmeme, the occurance of finite verb tagmas is very essential. In other words, without finite verb tagmas, there is no clause. As the occurance of finite verb tagmas in an English clause construction is obligatory, the ability to identify finite verb tagmas is compulsory. Due to limited time and resources, the data collected in this study is limited to ten sentences. The analysis is also limited to slot-role and four-cell analysis. It is, therefore, recommended that another study with more data and more detailed analysis using Tree diagrams can be conducted to reveal more interesting features and usage of finite verb tagmas in English.

\section{REFFERENCES}

Cook, W. (1969). Introduction to tagmemic analysis. Holt, Reinhart and Winston.

Harman, S. E., \& House, H. C. (1950). The descriptive English grammar. Englewood Cliff, N.J.: Prentice-Hall.

Hornby, A. S. (1975). Guide to patterns and usage in English. UK: Oxford University Press.

Wahab, A. (1990). Butir-butir linguistik. Surabaya: Airlangga University Press. 